UDK: $612.118(=497.2)$

doi:10.5937/gads1247317T

\title{
BLOOD-GROUP CHARACTERISTICS OF THE CONTEMPORARY BULGARIAN POPULATION FROM MIDDDLE MIZIA
}

\author{
Velislav Todorov, Cvetan Minkov, Nadežda Paraskowa, Danielo Pě̌ev, Angel Vasilev, \\ Martin Dimimtrov \\ Biološki fakultet, Sofijski univerzitet, ul. Dragan Cankov 8, Sofija, Bugarska
}

\section{Abstract}

In this investigation we studied the blood group affiliation of the Bulgarian population from Middle Mizia according to the ABO systems and Rhesus factor in connection with the complicated ethnos of the Bulgarians. The sample comprised 769 individuals of both sexes. The defined distribution of the groups from the $\mathrm{ABO}$ system was established in the studied population. The comparison with a control group from the Bulgarian population was made. The following differences were established - a decreased presence of the blood group A and an increasing of the blood group B and of the blood group $\mathrm{AB}$ The differences by the blood group A are significant. There are no differences by the Rhesus factor.

According to the group from Troyan, however, the data shows a presence of a mongoloid admixture. A significant decreasing of the blood group A was observed and weak presence of the negative Resus factor.
\end{abstract}

Key words: Blood-group systems, ABO, Rhesus factor, Middle Mizia

\section{Introduction}

The investigation of the blood group system is of big meaning for building up of fuller anthropological characteristic of a given population. Such attitude and Markovich (1994). Similar investigations in our country take up a particular place because of the complex ethnos of the Bulgarian people. In the investigations, carried out in our country up to now, the systems $\mathrm{ABO}$ and Rhesus factor are traced above all. The published results, up to now, of these investigations can be divided into of four groups by themes (subjects):

1. Regional investigations - at these examinations search eventual differences in the distribution of the separate groups (Todorov i sar. 1996,1997; Todorov et al. 2009; Minkov i sar. 2004).

2. A tie between the blood group belonging and the illness ( predisposition for the appearance and this development (Vizev i sar. 1986; Timceva i sar. 1998-1999, 2001; Todorov i sar. 2003, 2004, 2008, 2009, 2010; Максимова и сътр. 2008-2009; Maksimova i sar. 1997, 2002, 2006, 2007).

3. In ethnical aspect - an investigation of the blood group belonging at the ethnos, that inhabit our country (Todorov, Rubljova, 1986; Todorov i sar. 1993, 1998, 1998-1999; Todorov et al. 1983, 1991, 2005 ).

4. A studying of these traits in connection with the duration of the life (Todorov 1981, 1998-1999). 


\section{Material and methods}

In this investigation are studied 769 individuals (382 men and 437 women) from the following towns of Middle Mizia - Veliko Tarnovo, Gorna Oriachovitsa and Troyan. It was traced a blood group belonging of the systems $\mathrm{ABO}$ and Rhesus factor. In this study are used standard tests of serums. For this purpose the study was accomplished according to the cross method. It was accomplished a comparison of the received results with these one of the control group from the Bulgarian population. (1080 persons). It was realized by means of T-criterion according to formula offered from (Markovich, 1985). The results are presented on table 1-4.

\section{Results}

Blood group system $\mathrm{ABO}$. The received results are presented in table 1. At the examined excerpt was established the next distribution of the groups from the system: $\mathrm{O}$ group $-31,99 \%$, A group $-32,12 \%$, B group $-23,15 \%$ and $\mathrm{AB}$ group $-12,74 \%$. It was established the characteristic for Bulgarians arrangement of the separate groups $\mathrm{A}, \mathrm{O}, \mathrm{B}$, $\mathrm{AB}$. At comparison of the indexes of the relative share by means of $\mathrm{T}$-criterion, accomplished with control group, was established a bigger frequency of the cases with B group $(23,15 \%$ to $18,04 \%)$, a little higher frequency at group $\mathrm{AB}(12,74 \%$ to $7,59 \%)$ and practically the some values at $\mathrm{O}$ group $(31,99 \%$ to $31,67 \%)$. It is obvious the smaller frequency of the persons with A group toward this one at the control group (31,12\% to $43,70 \%)$. The established difference is statistically significant $(T=3,04, \mathrm{p}<0,01)$.

Table 1. A frequency of the blood groups in the population from Middle Mizia and from the control group

Tabela 1. Distribucija krvnih grupa sistemeABO na uzorku Srednje Mizije i kontrole

\begin{tabular}{|l|c|c|c|c|c|}
\hline \multicolumn{1}{|c|}{ grupa } & $\mathbf{N} / \%$ & O & A & B & AB \\
\hline $\begin{array}{l}\text { Srednja Mizija } \\
\mathrm{n}=769\end{array}$ & $\mathrm{~N}$ & 246 & 247 & 178 & 98 \\
\cline { 2 - 6 } $\begin{array}{l}\text { Kontrola } \\
\mathrm{n}=1080\end{array}$ & $\%$ & 31.09 & 31.12 & 23.15 & 12.74 \\
\cline { 2 - 6 } & $\%$ & 342 & 472 & 184 & 62 \\
\hline
\end{tabular}

Table 2. A frequency of the blood groups and $\mathrm{Rh}$ factor in the population from Troyan Tabela 2. Distribucija krvnih grupa sistemima ABO i Rezus faktora na uzorku iz Trojana

\begin{tabular}{|l|c|c|c|c|c|c|c|}
\hline \multicolumn{1}{|c|}{ grupa } & $\mathbf{N} / \%$ & $\mathbf{O}$ & $\mathbf{A}$ & $\mathbf{B}$ & $\mathbf{A B}$ & $\mathbf{R h}^{+}$ & $\mathbf{R h}^{-}$ \\
\hline \multirow{2}{*}{$\begin{array}{l}\text { Srednja Mizija } \\
\mathrm{n}=769\end{array}$} & $\mathrm{~N}$ & 71 & 35 & 65 & 29 & 182 & 18 \\
\cline { 2 - 8 } & $\%$ & 35.59 & 17.50 & 34.50 & 12.50 & 91.00 & 9.00 \\
\hline $\begin{array}{l}\text { Kontrola } \\
\mathrm{n}=1080\end{array}$ & $\mathrm{~N}$ & 342 & 472 & 184 & 82 & 916 & 164 \\
\cline { 2 - 8 } & $\%$ & 31.67 & 43.70 & 18.04 & 7.59 & 84.81 & 15.19 \\
\hline
\end{tabular}

At the processing of the collected material make an impression, that the excerpt from Troyan distinguish considerably according to the examined traits from the rest group of Middle Mizia. The results are presented in table 2. From this table we can see the biggest concentration of $\mathrm{O}$ group $-35,50 \%$, follows a group $\mathrm{B}-34,50 \%$, group $\mathrm{A}-17,50 \%$, and group $\mathrm{AB}-12,50 \%$. It is outlined a increased representation of $\mathrm{B}$ group (with 16,44\%) 
some increasing of $\mathrm{O}$ and $\mathrm{AB}$ groups (respectively with $3,83 \%$ and $4,91 \%$ ). The decreasing of the percentage at the persons with A group is significant (with 28,20\%, $\mathrm{T}=3,09, \mathrm{p}<0,01$ ).

The differences between the whole embraced contingent and the control are established and at comparison of their gene frequency. Particularly big is the difference at gene "p", more little at "r" and the most little at "q".

Table 3. Gen frequency of the population in the studied groups

Tabela 3. Distribucija gena kod obuhvaćenih grupa

\begin{tabular}{|l|c|c|c|}
\hline \multicolumn{1}{|c|}{ grupa } & $\mathbf{p}$ & $\mathbf{q}$ & $\mathbf{r}$ \\
\hline Srednja Mizija & 0.430 & 0.185 & 0.385 \\
\hline Trojan & 0.164 & 0.256 & 0.580 \\
\hline
\end{tabular}

Blood group system Resus factor. The results are presented in table 4. At the studied contingent is established a frequency of positive Rhesus factor of $84,65 \%$, and of the negative $-15,35 \%$. At comparison with the control group were established identically values (respectively $84,65 \%$ and $84,81 \%$ and $15,35 \%$ and $15,19 \%$ ). At the excerpt from town Troyan are established a significant increasing of the positive Rhesus factor $(91,00 \%$ $\mathrm{t}=2,35, \mathrm{p}<0,02)$.

Table 4. A frequency of Rh factor the population from Middle Mizia and from the control group

Tabela 4. Distribucija krvnih grupa sistema Rezus faktora na uzorku iz Srednje Mizije i kontrole

\begin{tabular}{|l|c|c|c|}
\hline grupa & $\mathbf{N} / \%$ & $\mathbf{R h}^{+}$ & $\mathbf{R h}^{-}$ \\
\hline \multirow{2}{*}{$\begin{array}{l}\text { Srednja Mizija } \\
\mathrm{n}=769\end{array}$} & $\mathrm{~N}$ & 651 & 118 \\
\cline { 2 - 4 } $\begin{array}{l}\text { Kontrola } \\
\mathrm{n}=1080\end{array}$ & $\mathrm{~N}$ & 84.65 & 15.35 \\
\cline { 2 - 4 } & $\%$ & 84.81 & 15.19 \\
\hline
\end{tabular}

\section{Discussion}

The results of the distribution of the blood groups from the system $\mathrm{ABO}$ at the examined contingent distinguishes from the normal distribution of the traits at the Bulgarians as a whole. It makes an impression the considerable increasing of the percentage frequency of the group $\mathrm{B}$. This phenomenon together with some increasing at $\mathrm{AB}$ and $\mathrm{a}$ significant decreasing of the percentages at group A, give us a reason to suppose, that in the Bulgarian ethnos from this region, are taken part and "eastern" elements. A special attention must pay to the group from Troyan. The arrangement of the separate groups $(\mathrm{A}, \mathrm{B}, \mathrm{O}, \mathrm{AB})$ distinguishes as from this one of the most Balcan populations, so and of the Bulgarians, generally. The big percentage at group B, the weak representation of group A and of the negative Rhesus factor shows, that in this region outline a presence of considerable " eastern" admixtures.

Our conclusion for a presence of "eastern" admixtures confirms and from more early leaded odontological investigations in the region of Troyan. (Minkov T, 1976) establishes an increased percentage frequency of shovel-shaped upper medial incisors $(33 \%)$ in the studied population from this region. This is an indication for a presence of "eastern" admixture in 
the ethnos of the studied population. It is known that at the europoid population the percentage of the showel-shapeness of the incisors in the limits between 125 and $15 \%$.

\section{Conclusion}

1. The studied population by the blood group traits characterize like a europoid population, but with a presence of "eastern" elements in its ethnos.

2. The excerpt from the region of Troyan distinguishes with considerably "eastern" admixture by the studied traits, that confirm as historical and other investigation in this region.

\section{References}

Markovic M. Blood groups of $\mathrm{ABO}$ system and $\mathrm{Rh}$ factor in 260 pairs of twins and 11 triples. Variability and Evolution. 1994;4:97-102.

Marinkovic D, N Tucic, V. Kekić. Genetika, Naučna knjiga, Beograd. 1985;417-430.

Maksimova S, Todorov V, Timceva A. Sistemi krvnih grupa ABO i Rezus factor kod nekih oboljenja od socialnog znacaja. Glasnik antropoloskog drustva Jugoslavije. 1997;33:119-124.

Maksimova S, Todorov V, Timceva A. Pripadnost krvnim grupama iz sistema ABO iRezus factor i kardiovaskularna oboljenja. Glasnik antropoloskog drustva Jugoslavije. 2002;37:271-275.

Maksimova S, Todorov V, Hristova. Neoplazeme i krvne grupe sistema ABO i Rezus factor. Glasnik antropoloskog drustva Jugoslavije. 2006;41:425-428.

Maksimova S, Todorov V, Hristova. Karcinom na zelucu kao deo neoplazmi probave. Glasnik antropoloskog drustva Jugoslavije. 2007;42:454, 35-37.

Minkov Tsv, Paraskova N, Todorov V. Antropoloska karakteristika bugarskog stanovnistva u nekim rejonima Zapadne Trakije prema antropofizioloskim I seroantropoloskim obelezjima. Glasnik antropoloskog drustva Jugoslavije. 2004;39:87-92.

Timceva A, Maksimova S, Todorov V. Raspodela krvnih grupa ABO sistema i Rh factor kod pacijenata za cirom jetre I hronicnim hepatitisom. Glasnik antropoloskog drustva Jugoslavije. 1998;34:203-204.

Todorov V. Krvne grupe osoba iznad 60 godina starosti. Glasnik antropoloskog drustva Jugoslavije. 1982;1:199-204.

Todorov V, Jordanova K, Liposhlieva Tz. Blood group characterization of the ethnikal groups in Bulgaria. God. zb. Med. fak., Skopje, 29(2):177-178.

Todorov V, Rubljova M. Karakteristika krvnih grupa Grka I Armena. Posebno izdanje antropoloskog drustva Jugoslavije. 1986;9:111-116.

Todorov V, Rubljova M, Minkov Tsv. Distribucija glavnih krvnih grupa ABO sistema i Rh factor u uzorku Jevreja u Sofiji. Glasnik antropoloskog drustva Jugoslavije. 1988;25:81-84.

Todorov V, Bozikova G, Kicheva M. Blood groups belonging to $\mathrm{ABO}$ and $\mathrm{Rh}$ systeme from two ethnic groups. Furst national conference of Anthropology with international participation, Plovdiv. 199:183-185.

Todorov V, Maksimova S, Radkova M. Sistemi krvnih grupa ABO I Rh factor kod dve narodnosti sa razlicitom etnogenezom. Glasnik antropoloskog drustva Jugoslavije. 1993;29:83-86.

Todorov V, Daskalova V, Maksimova S. Karakteristika krvnih grupa kod stanovnistva Devinskog regiona. Glasnik antropoloskog drustva Jugoslavije. 1996;2:29-32.

Todorov V. Promene antropoloskih karakteristika u toku starenja. Doktorska disertacija. Beograd 1998-1999;72-77.

Todorov V, Maksimova S, Angelova V. Sistemi krvnih grupa ABO I Rh factor kod raznih etnickih grupa koje zive u Bugarskoj. Glasnik antropoloskog drustva Jugoslavije. 1998;34:209-213.

Todorov V, Maksimova S, Hristova V. Krvnogrupna pripadnost sistemima ABO I Rh factor kod pacijenata sa apendektomijom. Glasnik antropoloskog drustva Jugoslavije. 2004;39:83-84.

Todorov V, Minkov Tsv., Paraskova N. Blood belonging, menarch and menopaus in Armenians in Bulgaria. Glasnik antropoloskog drustva Jugoslavije. 2005;40:187-191. 
Todorov V, Maksimova S, Hristova V. Karcinom mokracne besike i krvne grupe. Glasnik antropoloskog drustva Jugoslavije. sv. 2009;43:72-74.

Todorov V, Minkov Tsv, Tosheva N, Minkov B. Blood group characterization of Bulgarian population from the regions of Panagurishte and Strelca. Glasnik antropoloskog drustva Jugoslavije. 2009; 44:357-378.

Todorov V, Maksimova S. Povezanost izmedju krvnih grupa ABO i Rh sistema ipojave karcinoma pancreasa. Glasnik antropoloskog drustva Jugoslavije. 2010; 45:187-190.

Vizev St., Todorov V. ABO krvnogrupni system kao factor rizika za razvoj ateroskleroze. Posebno izdanje antropoloskog drustva Jugoslavije. 1986;9:117.

Максимова С, Тодоров В, Христова В. Калкулоза на бъбрека и пикочния мехур в кръвногрупов аспект. Андрология. 2008; кн.4:7-8.

Максимова С, Тодоров В, Янев Кр, Панчев П. Новообразувания и кръвногрупова принадлежност към системите ABO и Rh фактор. Андрология. 2009;кн.4:9-11.

Тимчева A, Тодоров В, Максимова С. Кръвногрупови системи ABO и Rh фактор при диабетно болни с гангрена. Медицинска наука. София 2001;кн.2:20-24.

Тодоров В, Максимова С, Христова В, Цветков Д. Честота на хидроцеле и варикоцеле в контекст на кръвните групи по системите $\mathrm{ABO}$ и $\mathrm{Rh}$ фактор. Андрология. 2003;т.12,кн.3:17-19.

\title{
KRVNO-GRUPNE KARAKTERISTIKE SAVREMENOG BUGARSKOG STANOVNIŠTVA SREDNJE MIZIJE
}

\author{
Velislav Todorov, Cvetan Minkov, Nadežda Paraskowa, Danielo Pešev, Angel Vasilev, \\ Martin Dimimtrov
}

\section{Sažetak}

Istraživana je krvno-grupna pripadnost stanovništva Srednje Mizije sistemima ABO i Rezus faktor u vezi sa složenom etnogenezom Bugara. Obuhvaćeno je 769 lica oba pola. Pri poređenju sa podacima bugarskih populacija konstatuje se manja zastupljenost A grupe, očigledno veća kod B grupe i veća kod AB u Srednjoj Miziji. Značajne su razlike kod A grupe $(p<0,01)$. Kod Rezus faktora ne nalazimo razlike. U uzorku iz Trojana konstatuju ce značajno smanjenje distribucije A grupe i mala zastupljenost negativnog Rezus faktora.

Ključne reči: Krvno-grupni sistemi, ABO, Rezus faktor, Srednja Mizija 